\title{
Helping Women Entrepreneurs Succeed: What's Needed Now
}

\author{
Kimberly Eddleston (Northeastern University)
}

KEYWORDS: Entrepreneurship, Leadership, Women, Higher Education.

The number of successful women entrepreneurs is growing, but much more needs to be done to support them now and prepare future generations of women leaders. In this second part of a two-part interview (https://eiexchange.com/content/376-breaking-norms-to -get-ahead-do-women-entrepreneurs-need-a-dash-ofpsychopathy), EIX editor Kim Eddleston talks with successful entrepreneurs Sandra Powers Murphy and Susan Penta about how teachers, universities, private organizations (including the Center for Women \& Enterprise(https://cweonline.org/), where Penta is a board member) and the rest of the business community can work together to encourage entrepreneurial women. Mentorship, funding from university endowments, support and encouragement from already-successful women business owners, and organizations that champion women in business are all part of the mix.

\section{Read More}

Advice, Best Practices and Inspiration for Women Entrepreneurs(https://eiexchange.com/women)

Additional search terms: women, feminism, female founders, women business owners, glass ceiling, sexual discrimination, sexual harassment, bias, opportunity, entrepreneurship school, college business programs, MBA programs, business schools 